https://doi.org/10.52058/2786-4952 -2021-5(5)-701-712

Якименко Поліна В'ячеславівна кандидат педагогічних наук, доцент кафедри психології та педагогічної освіти, Міжнародний класичний університет ім. Пилипа Орлика, вул. Котельна, 2, м. Миколаїв, 54003, тел.: (0512) 59-30-01, e-mail: serdolik1@ @otmail.com, https://orcid.org/0000-0002-4233-4098

\title{
ІСТОРИЧНІ АСПЕКТИ РОЗВИТКУ ПРОФІЛЬНОГО НАВЧАННЯ
}

Анотація. Стаття присвячена аналізу ідей профільного навчання, висвітлено вітчизняний та зарубіжний досвід профілізації навчального процесу в старшій школі; проаналізовано особливості допрофільної та профільної підготовки учнів відповідно до чинної нормативної бази.

Здійснено ретроспективний аналіз теорії профільно-диференційованого навчання та узагальнено досвід запровадження різних моделей профільного навчання у вітчизняному шкільництві. Розкрито сутність поняття «профільне навчання», визначено значимість та пріоритети цього явища у системі сьогоднішньої освіти.

Запровадження профільного навчання у старшій школі $є$ одним із пріоритетних напрямів оновлення сучасної освіти, підвищення іiї якості, що дозволяє за рахунок зміни у структурі, змісті й організації освітнього процесу враховувати інтереси та здібності учнів, створювати умови для їхньої освіти відповідно до професійних інтересів та життєвих планів.

На шляху реалізації змін у сучасній середній освіті вагоме значення займає переосмислення накопиченого досвіду впровадження профільного навчання в історії зарубіжної та вітчизняної школи, що сприяє осмисленню генези шкільної профілізації як цілісного педагогічного знання, узагальненню результатів та здобутків теорії і практики профільного навчання, врахування яких важливе при розв'язанні наукових і практичних завдань реформування української освіти.

Аналіз зарубіжних джерел показав, що старші школи в усіх розвинених країнах $є$ профільними, їх сучасна структура $\epsilon$ результатом генералізації й уніфікації структури та змісту освіти упродовж кількох десятиріч. У системі організації навчання на старшому ступені можна виявити такі загальні тенденції: значну варіативність навчання у старшій школі на основі запровадження великої кількості академічних і професійних програм з метою якнайбільшого задоволення потреб ринку праці та особистісних сподівань кожного індивідуума

Профілізація $є$ основою успішної соціалізації особистості, тому що спрямована на гуманізацію освіти, задоволення освітніх потреб, поширення індивідуалізації та диференціації в навчанні, впровадження інформаційних 
технологій і педагогічних інновацій, здійснення неперервної професійної освіти.

Ключові слова: профільне навчання, профільна школа, диференціація, профільна диференціація, профіль, профільне навчання.

Yakymenko Polina Viacheslavivna Candidate of Pedagogical Sciences, Associate Professor Department of Psychology and Pedagogy Philip Orlyk International Classical University Private institution of higher education, Kotelna St., 2, Mykolaiv, 54003, tel.: (0512) 59-30-01, e-mail: serdolik1@ hotmail.com, https://orcid.org/0000-0002-4233-4098

\title{
HISTORICAL ASPECTS OF PROFESSIONAL TRAINING DEVELOPMENT
}

\begin{abstract}
The article is devoted to the analysis of ideas of profile education, the domestic and foreign experience of profiling of educational process in senior school is covered; the peculiarities of pre-profile and profile training of students in accordance with the current regulatory framework are analyzed.

A retrospective analysis of the theory of profile-differentiated education is carried out and the experience of introduction of different models of profile education in domestic schooling is generalized. The essence of the concept of "specialized training" is revealed, the significance and priorities of this phenomenon in the system of today's education are determined.
\end{abstract}

The introduction of specialized education in high school is one of the priority areas of renewal of modern education, improving its quality, which allows due to changes in the structure, content and organization of the educational process to take into account the interests and abilities of students, create conditions for their education. .

On the way to change in modern secondary education it is important to rethink the experience of implementing specialized training in the history of foreign and domestic schools, which helps to understand the genesis of school profiling as a holistic pedagogical knowledge, generalization of results and achievements of theory and practice of specialized training. linking scientific and practical tasks of reforming Ukrainian education.

Analysis of foreign sources has shown that high schools in all developed countries are specialized, their current structure is the result of generalization and unification of the structure and content of education for several decades. The following general tendencies can be found in the system of organization of education at the senior level: significant variability of education in high school on the basis of introduction of a large number of academic and professional programs for the purpose of the greatest satisfaction of labor market needs and personal expectations of each individual.

Profiling is the basis of successful socialization of the individual, because it 
aims to humanize education, meet educational needs, spread individualization and differentiation in learning, the introduction of information technology and pedagogical innovations, the implementation of continuing professional education.

Keywords: profile training, profile school, differentiation, profile differentiation, profile, profile training.

Постановка проблеми. Як зазначено в Концепції профільного навчання у старшій школі, розвиток світового i, зокрема, європейського освітнього простору, вимагає «від української школи адекватної реакції на процеси реформування загальної середньої школи, що відбуваються у провідних країнах світу. Загальною тенденцією для старшої профільної школи $\epsilon$ iii орієнтація на широку диференціацію, варіативність, багатопрофільність, інтеграцію загальної і допрофесійної освіти» [1]. Профільне навчання є одним із видів диференціації навчання, тобто такої форми організації навчальної діяльності середнього і старшого шкільного віку, за якої враховуються їх здібності, схильності та інтереси [1].

Аналіз останніх досліджень i публікацій. проблеми профільного навчання розглядали багато вітчизняних та зарубіжних науковців, зокрема А. М. Сгорова, Л. Я. Зеня, А. Е. Касенова, В. І. Кизенко, К. В. Корсак,

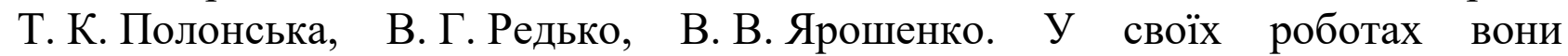
розглядають широкий спектр питання, пов'язаних із профільним навчанням, зокрема рівень готовності учнів до вибору майбутньої професії; підготовку вчителів до викладання профільних предметів та спеціальних курсів; особливості конструювання змісту рівневого навчання у старшій профільній школі тощо.

Мета статті. проаналізувати та узагальнити поняття профільне навчання вітчизняний та зарубіжний досвід профілізації шкільного навчання; окреслити тенденції розвитку профілізації на сьогоднішній час.

Виклад основного матеріалу. Лінгвістичне визначення поняття «nрофіль» містить сукупність основних рис, що характеризують професію, спеціальність, господарство. Інші джерела погоджуються з такою дефініцією, вносячи доповнення, які не змінюють сутності визначення.

Згідно з цим поняттям, профільне навчання в освітньому закладі розглядається як навчальна праця, що спрямована на вивчення освітніх галузей, які містять типові знання, вміння і навички, що є характерними для певної сфери діяльності, професії, спеціальності.

Такий підхід до формування змісту освіти за профілями виходить із ідеї реалізації більш широкого профілю, ніж це прийнято в школах з поглибленим вивченням окремих предметів (у спецшколах). 3 огляду на це ми можемо сказати, що профіль представляє собою перехідну форму диференціації навчання - 3 одного боку, між традиційним універсальним підходом i, з іншого боку, глибокою спеціалізацією, що $є$ характерною для ліцеїв та спецшкіл (математична школа, хімічний клас і тощо.). Слід зазначити, що, як свідчить 
практика, подібна форма спеціалізації («профіль як спецшкола») також цілком може реалізовуватися в прийнятих концептуальних рамках, коли практично весь зміст відводиться «предметно-жорстко» на поглиблення двох-трьох профільних дисциплін.

У дослідженні ми виходимо 3 того, що профілі, які представлені в Концепції профільного навчання, не складають вичерпного переліку; у ряді шкіл, - із урахуванням потреб учнів, можливостей школи, особливостей місцевої освітньої мережі регіону, соціального замовлення та інших факторів відкриваються й інші профілі, у тому числі й як спеціалізації провідних профілів (медичні, агротехнологічні, літературні, педагогічні тощо.).

Відповідно, профільність визначається як надання навчальному закладу, установі, класу, групі, навчальному процесу тощо спеціального характеру, напрямку. У даному контексті профільна школа - це середній навчальний заклад, у якому у старшій школі навчальні інтереси (зокрема - професійні) та можливості учнів у цілому визначилися, а профіль навчання - спосіб організації диференційованого навчання, який передбачає поглиблене та професійно зорієнтоване вивчення циклу споріднених предметів (див. там же).

За визначенням А.П. Самодрина, профільне навчання - це профільнодиференційована (за спорідненістю індивідуальних профілів) планомірна, організована, спільна двостороння діяльність учителя і учнів, спрямована на свідоме, міцне i глибоке опанування останніми системи профільно орієнтованих знань, умінь і навичок, під час якого поряд із загальною освітою (освітнім ядром) набувається особистісно зорієнтована допрофесійна підготовка (освітня периферія) - разом становить зміст профільної освіти.

У Л. В. Голуб «профільне навчання» - це те, що ширше за професію, водночас $є$ стрижнем професії (кількох майбутніх спеціалізацій навчання у ВНЗ). Тобто профіль у середній школі - це не що інше, як допрофесійно орієнтована навчальна діяльність на відрізку школа - ВНЗ.

Профільне навчання є одним із видів диференціації навчання - форми організації навчальної діяльності середнього і старшого віку, за якої враховуються їх схильності, інтереси, здібності (П. С. Лернер, М. Ф. Родичев, С.Н.Чистякова). Педагогічний принцип диференціації не допускає зниження загального (базового) рівня загальноосвітньої підготовки учнів.

Нам близькі погляди О.М. Леонтьєва, який зауважив, що мотивована соціальними цінностями діяльність $є$ умовою переходу індивідуальності в соціальність, а профільна діяльність цей рівень переходу значно посилює в кращий бік [2].

Перша спроба здійснення профільного навчання була зроблена у 1864 р. Вона забезпечувалася організацією семикласних гімназій двох типів: класична (мета - підготовка до вступу в університет) і реальна (підготовка до практичної діяльності та до вступу у спеціалізовані навчальні заклади).

У 1913 році в полі зору вітчизняної освіти виникає проблема створення «трудової школи». Ідея трудової школи була запозичена у фундаторів 
утопічного соціалізму Т. Мора і Т. Кампанелли. На початку XX сторіччя ця ідея була частково втілена в життя Г.Кіршентштейнером та Дж. Д’юї.

Розробці окремих аспектів ідей трудової школи як одному із пріоритетних напрямків реформування вітчизняної освіти багато уваги присвятили К.Д. Ушинський, В.М. Бехтєрєв, Г.І. Россолімо, О.П. Нечаєв та ін.

Побудова школи нового типу базувалася на педології як науці про розвиток дитини. Умовою педагогічного процесу було залучення «побутового аспекту; природних, соціальних i культурних чинників середовища; генетичних, фізіологічних, психологічних, соціальних характеристик» [3; с.29]. За концептуальними положеннями педагогів-фундаторів трудової школи, діти, беручи участь у суспільно корисній праці та змінюючи навколишнє середовище відповідно до здобутих у школі знань, умінь та навичок, перетворюють свій ціннісно-емоційний світ, оволодівають соціально значущими видами діяльності.

Iз 1918 р. на основі Положення про єдину трудову школу відбувалася подальша профілізація старшої школи. У старшому ступені середньої школи виділялося три напрями: гуманітарний, природничо-математичний та технічний. Чималий досвід із запровадження трудової школи був накопичений відомими педагогами С. Т. Шацьким та А. І. Пінкевичем.

У початковій школі було зроблено крок до практицизму з гіпертрофією праці (1918-1931). Так, у шкільну практику впроваджувалися комплексні програми, автори яких розташовували навчальний матеріал за принципом вивчення трьох сторін: природи, суспільства, праці. У процесі навчання учень поступово йшов від безпосереднього природного та соціального оточення до більш узагальнених категорій.

У 1920-х роках в Україні «трудовий принцип з новим змістом» також стає пріоритетом у навчанні і професійній підготовці школярів.

Новою спробою радянської школи вплинути на суспільство був перехід у 1931 році від штучного абстрактного змісту навчання до формування в учнів об'єктивно-предметних (політехнічних) уявлень про виробництво. Система освіти уніфікується, професійні школи реорганізуються в середні спеціальні заклади, з'являються такі види профільних шкіл, як ФЗУ (фабрично-заводське учнівство) та школи сільської молоді.

У результаті мілітаризації країни академічна школа в цей час набуває ознак наближення до прикладної школи. Посилюються вимоги до професійної підготовки через інтеграцію інтелектуально-прикладних зв'язків у іiі змісті. Виникає нова потреба у трудовій школі.

У 1934 р. схвалено постанову «Про структуру початкової і середньої школи СРСР», що передбачала єдиний навчальний план та єдині навчальні програми.

У 1940 році у СРСР утворюється система державних трудових резервів, у склад яких переходять і профільні школи.

Спроба поєднання навчання із виробничою працею відбулася у 1950-1960 
роках. Педагогічною практикою в цей час було підтверджено, що поєднання 3 виробничою працею не означає механічної добавки праці до навчання i вимагає суттєвого коригування змісту, форм і методів навчання, а також удосконалення способів організації трудової діяльності учнів.

У 1957 p. 3 ініціативи Академії педагогічних наук розпочався експеримент, завданням якого було проведення профільної диференціації за трьома напрямками: фізико-математичним та технічним; біологоагрономічним; соціально-економічним і гуманітарним. У 1958 створюються спеціалізовані школи для обдарованих дітей: фізико-математичні, спортивні, музичні, художні, з поглибленим вивченням іноземних мов тощо.

3 метою подальшого покращення роботи середньої загальноосвітньої школи у 1966 р. запроваджується така форма профільної диференціації за інтересами школярів, як факультативні заняття у 8-10 класах. У цей час педагогічною наукою закономірно ставилося питання про необхідність взаємозв'язку факультативних занять 3 класними заняттями та позакласною роботою, урахування вікових особливостей учнів і надання їм допомоги щодо усвідомленого вибору факультативних курсів, системної роботи протягом ряду років на основі факультативних курсів з різних навчальних предметів.

Однією із ключових проблем даних реформувань була відсутність дидактичної класифікації та системи факультативних занять, які б практично забезпечили реалізацію їх функцій. За три десятки років було опрацьовано лише 45-50 факультативів для старшого ступеня середньої загальноосвітньої школи. Не приділялося належної уваги навчально-методичному забезпеченню факультативних занять [4].

Професійна орієнтація в загальноосвітніх навчальних закладах здійснювалася на базі широкої загальної і політехнічної освіти і не передбачала ранньої професіоналізації. Вважалося, що чим більш широкою та грунтовною $\epsilon$ освіта, тим більше можливостей зробити більш обгрунтований, правильний вибір професії. Брак певних механізмів професійного самовизначення система профорієнтації в середній школі компенсувала засадами обов'язковості гуртків, секцій, факультативів, роботою на колгоспних полях тощо. Специфіка суспільно корисної праці використовувалася у підготовчій роботі з визначення учнями майбутньої професії.

У процесі профорієнтаційної роботи учні отримували необхідні знання про масові професії. На цьому етапі розвитку освіти стало доцільним внести в зміст освіти середньої школи допрофесійний компонент (Є. О. Климов, А. Д. Сазонов, В. Д. Симоненко, Б. О. Федоришин та ін.)

З 1987 року для учнів 7-8 класів був введений навчальний предмет «Основи виробництва. Вибір професії».

Відносно стійкі потреби суспільства викликали у 1966 році створення шкіл (класів) з поглибленим вивченням предметів. В наступні роки вперше до навчальних планів вводяться етика, бальні танці, хореографія, музика та рух, риторика, основи журналістики, на початку 90-х років вводяться курси історії 
релігії та національної культури, фольклору та етнографії України тощо.

У 80-х роках 3'являються нові види загальноосвітніх закладів (ліцеї, коледжі, гімназії), що орієнтовані на поглиблене вивчення обдарованими учнями в професійно-профільованому навчанні тих чи інших освітніх галузей за вибором 3 метою подальшого навчання у вищих навчальних закладах. Основним завданням цих специфічних навчальних закладів $\epsilon$ підготовка інтелектуальної національної еліти. Їхні академічні традиції у навчанні починаються 3 відомих в історії України братських шкіл XVI-XVII ст. Розвивалися спеціалізовані (до певної міри - профільні) школи. При всій різноманітності форм і методів роботи шкіл нового типу, не зважаючи на певну розмитість цілей та неясність шляхів їх досягнення, діяльність цих навчальних закладів поступово переходила від експериментальної спрямованості до режиму виконання узгоджених та затверджених відповідними освітянськими органами навчальних планів та програм.

Пріоритетними напрямками діяльності даних навчальних закладів наголошувалися: розробка нових і корекція існуючих навчальних програм i планів; визначення науково обгрунтованого змісту викладання предметів, його обсягу і якості; пошук нестандартних форм і методів активізації навчальної діяльності; поліпшення структури навчального режиму роботи школи; демократизація освітнього процесу; комп'ютеризація навчання. На засадах педагогічних експериментальних майданчиків дані навчальні заклади поступово формували підступи до профільно-диференційованого навчання. Педагоги-новатори, керівники шкіл ставали науковцями (В.М.Алфімов, М.П.Гузик, С.М.Січко, А.І.Сологуб, В.М.Хайруліна та ін.).

У 80-90-ті роки розвивалася лекційно-практична система навчальних занять (що була запропонована в Україні ще на початку 60-х років О.О. Хмурим). Надавалися можливості для активізації самоосвіти учнів, розвитку індивідуальних здібностей, інтересів. Змінювалася роль вчителя, який переставав бути передавачем інформації та набував рис наукового керівника, консультанта в організації навчального процесу. Розвиваються нестандартні уроки: урок-лекція, урок-семінар, урок-консультація, урок-залік, урокпрактикум тощо. Подальше удосконалення лекційно-практичної системи відбувалося у різнорівневій диференціації навчання, апробації нового змісту освіти, впровадженні інноваційних педагогічних технологій.

Такі ознаки, як відсутність на той час у більшості шкіл нового типу належної матеріально-технічної бази, недостатньо розробленої концепції освітньої діяльності, учителів, що володіють новими технологіями навчання, відповідної нормативно-правової бази тощо, не зупинили батьків від вибору для своїх дітей саме цих закладів.

У 1990-ті роки загальноосвітня школа отримала так званий інваріант (стандарт) і варіативну диференційовану частину. У нормативних документах варіативна частина отримала назву «Шкільний компонент».

Одним із головних надбань вітчизняної освіти в ці роки $є$ те, що стало 
можливим створення різноваріантних типів сільських шкіл, у яких також здійснювалася профільна підготовка або поглиблене вивчення тих предметів, що потрібні були для продоуження освіти у спеціальних середніх та вищих навчальних закладах або до праці у сільській місцевості.

Для більш ранньої професійної орієнтації учнів середніх шкіл, створення умов для підвищення якості навчання і виховання на основі наступності всіх ступенів і рівнів освітньої системи та поліпшення якісного складу студентів вищих навчальних закладів за рахунок диференційованої підготовки у середніх закладах при університетах формувалися науково-навчальні комплекси. Цілеспрямованість у довузівській підготовці певним чином впливала на конкурсну ситуацію та на якісний склад студентів.

Довузівська підготовка поступово спрямовувалася до ширшого залучення підготовленої сільської молоді до вступу в університети. Відкривалися профільні класи в сільських школах. Досить ефективною щодо відкриття таких класів була робота на базі навчально-виробничих комбінатів.

Вся ідеологія профільного навчання обумовлювала значний ступінь

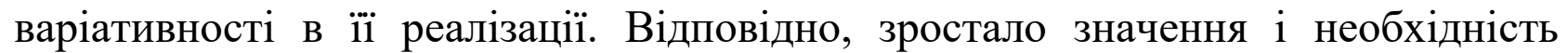
чіткого проектування i організації передпрофільної підготовки учнів випускних класів основної школи.

За таких умов в системі освіти виникла тенденція до охоплення академічною школою усього освітнього простору середньої школи. Завдання політехнічної підготовки, зазначає вчений, не вичерпуються вивченням лише основ наук: навчання не повинно зводитися до передачі роздрібнених і не взаємозв'язаних знань і умінь, воно повинно здійснюватися таким чином, щоб все пізнане в теорії закріплювалось практикою. Завдання повинні розв'язуватися за допомогою трудового навчання, виробничої праці, політехнічних практикумів і технічної творчості.

Виникає потреба, враховуючи досвід минулого, у тому числі української народної педагогіки, взяти до уваги і нові підходи до трудової підготовки учнів, зумовлені переходом України до ринку. Так, 90-ті роки ознаменувалися широким використанням у трудовому навчанні досвіду народної педагогіки, ознайомленням школярів 3 історією i розвитком ремесел, народними художніми промислами. Учні шкіл нового типу також залучалися до ручної праці, вивчення трудових традицій народу.

Навчання пов’язувалося 3 історією рідного краю, України загалом. Для цього використовувалися можливості місцевих краєзнавчих музеїв, екскурсії по рідному краю. Знайомлячись з технологічними аспектами виготовлення виробів народної творчості, учні починали цікавитися різними ремеслами та пов'язаними з ними галузями виробництва.

Із середини 90-х років у всіх типах навчальних закладів певного профілю домінуючою стає сфера навчання, зокрема специфічної професійної орієнтації чи фахової підготовки. Обов'язковим у них є базовий зміст освіти (державна програма), але є можливість для варіативності системи навчання, широкої 
автономії щодо введення нових предметів і розподілу навчального часу. Згідно 3 цим у загальноосвітніх навчальних закладах рівновеликими були всі типи навчальних дисциплін: суспільно-гуманітарний, природничий, технічноприкладний. У всіх інших закладах один iз них міг займати пріоритетну позицію за кількістю годин та предметів і за характером вивчення.

На базі деяких районних середніх загальноосвітніх шкіл також створювалися ліцеї, гімназії. У малонаселених пунктах, як свідчать дослідження М.В. Паюл [5; с.186], не завжди було доцільним створювати ліцеї з ряду об'єктивних причин, перш за все - демографічної: малої кількості дітей шкільного віку (від 15-30 до 100-120 дітей). У таких селах віддавалася перевага створенню таких нових типіу навчальних закладів, як навчально-виховні комплекси. Як правило, це були міні-комплекси 3 такими центрами, як культурно-освітній, спортивний, виробничий, де учні не лише навчалися, а й за бажанням працювали та одержували грошову винагороду за свою працю. Робота даних комплексів проектувалася за індивідуальними планами та проектами, а не за загальними стандартами. При цьому враховувалися місцеві та регіональні особливості та потреби у професіях.

Головними функціями технологій навчання у даних міні-школах та малокомплектних школах були:

- забезпечення усім дітям обов'язкового достатнього рівня знань, що надавав би учневі реальну змогу здійснювати безперервну освіту;

- реальне здійснення рівневої диференціації у навчанні учнів, орієнтованої на конкретну цільову спеціальну або профільну підготовку учнів;

• забезпечення умов для індивідуалізації навчання учнів (наявність детально розроблених загальних $\mathrm{i}$ предметних цілей навчання та виховання; наявність альтернативних варіантів дидактичних комплектів для учнів та учителів 3 різних предметів; використання доступних моделей навчання 3 різних навчальних предметів; використання нетрадиційних методів та форм навчання; впровадження нетрадиційних енергомістких технологій навчання);

- здійснення національного та патріотичного виховання та навчання майбутніх громадян України, iii захисників, працівників, свідомих цивілізованих власників та господарів землі [5, с. 187-188].

При створенні нових типіу навчальних закладів у сільській місцевості бралися до уваги специфіка і потреби села. Нові навчальні програми, курси та факультативи орієнтувалися на спеціальності сільськогосподарського профілю. Враховувалися особливості роботи даних навчально-виховних закладів в умовах сільської місцевості. Специфіка села, 3 огляду на його сільськогосподарське оточення, соціально-економічні та демографічні особливості, вимагала створення відповідних навчальних закладів, що забезпечували надання освітніх послуг для даного конкретного району, задоволення потреб даного господарства. При цьому здійснювалися спроби 
Журнал«Герспективитаінновації наукиљ

(Серія«Гедагогіка»), Серія«ГТихологія», Серія «Медицина»

№5(5) 2021

науково обгрунтовувати (із соціально-економічної точки зору) доцільність відкриття того чи іншого профілю освітнього закладу нового типу в сільській місцевості.

Так, з точки зору В.О. Соловйова [6, с.189], при створенні закладів нового типу в умовах села треба виходити з того, що:

- матеріальна база сільських шкіл значно слабша від міських;

- більшість шкіл на селі нечисельні, що створює проблему пошуку та відбору необхідної кількості учнів для цих закладів;

• проблематичність оптимального вибору місця для розташування цього закладу, щоб воно задовольняло переважну більшість учнів;

- слабке кадрове забезпечення сільського навчально-виховного закладу викладачами належної кваліфікації;

- віддаленість села від далеких промислових, адміністративних, наукових та культурних осередків, що зумовлює погіршення зв'язку 3 науково-дослідними установами, вищими та середніми спеціальними навчальними закладами, викликає труднощі в організації якісного навчально-виховного процесу;

- малозабезпеченість новими за змістом та рівнем підручниками та навчальними посібниками, а також методичними та дидактичними матеріалами.

Проблеми профілізації старшої школи, а саме - взаємодії професійної і загальної освіти в загальноосвітній школі, викликали необхідність звернення до кращого зарубіжного досвіду з цієї проблематики.

В останнє десятиріччя XX століття важливим напрямком державної політики розвинених країн Заходу стала розробка на регіональному та національному рівнях спеціальних програм у галузі навчальної профорієнтації.

Провідну роль в організації профільного навчання на початку 90-х років в Україні відігравали школи нового типу. При цьому лише $40 \%$ учнів керувалися власною схильністю до вивчення предметів певного профілю.

Для подальшого розвитку суспільства, створення механізму виконання соціального замовлення та задоволення освітніх потреб учнів виникла потреба у створенні моделі сучасної масової загальноосвітньої школи. Перед освітою України постало завдання подальшої розробки теоретичних і практичних засад профільного навчання.

У 2003-2004 роках в Україні створюється в основному фундамент для переходу вітчизняної старшої школи на профільне навчання.

Висновки. Отже, ретроспективний аналіз профільного навчання як педагогічної проблеми свідчить про наступне:

- забезпечується взаємообумовленість навчання в загальноосвітніх навчальних закладах академічної і прикладної підготовки на засадах профільно-професійної соціалізації;

- на різних рівнях школи формуються такі вміння, як наукова організація праці, моделювання майбутньої діяльності, конструкторсько- 
технологічна діяльність, знаходження рішення в кризових ситуаціях, самостійне творче мислення тощо;

- створюються можливості до реалізації допрофесійної функції в роботі з обдарованими дітьми;

- посилюється мотивація навчального процесу в школі;

- налагоджується зв'язок між соціально-економічною ситуацією в країні (регіоні) та змістом освіти;

- збільшується тенденція профілізації середньої освіти для більш ефективного соціально-економічного росту країни;

- змінюється роль учителя в навчальному процесі: учитель стає не транслятором знань, а організатором колективного навчального процесу, самостійної роботи учнів, індикатором засвоєння знань та умінь;

- профільне навчання, як показує досвід багатьох країн, може бути спрямованим на забезпечення інтересів, здібностей та індивідуальних можливостей учнів відповідно до їх майбутніх життєвих планів шляхом диференціації та індивідуалізації навчання, забезпечення рівних можливостей.

Разом $з$ тим:

- функціонування шкіл різного типу в Україні лише частково вирішує проблему профілізації старшої школи, певним чином обмежуючи рівний доступ до якісної освіти;

- існуючі стандарти загальної середньої освіти недостатньо відбивають основні підходи до профілізації старшої школи в Україні;

- система підготовки та підвищення кваліфікації учителів недостатньо враховує проблеми профілізації старшої школи.

Таким чином, поряд із іншими проблемними аспектами профілізації старшої школи постає проблема підготовки педагогічних кадрів нової формації з допрофільної та профільної (у тому числі - допрофесійної) підготовки.

\section{Лimepamypa:}

1. Концепиія розвитку освіти Украӥни на період 2015-2025 років (проект) (2014). URL: http://old.mon.gov.ua/ua/pr-viddil/1312/1390288033/1414672797/

2. Леонтьев А.Н. Деятельность. Сознание. Личность. Избр. психол. произведения в 2-х т. Т.1.М.: Педагогика, 1983. 291 с.

3. Дичківська I.M. Основи педагогічної інноватики: Навч.посібник. Рівне, 2001. 222 с.

4. Вороніна Л.П., Кизенко В.І. Факультативні заняття як засіб диференціації навчання в основній школі. Педагогіка: Науково-методичний збірник. Вип.31. К.: Освіта, 1992. С. 14-17.

5. Паюл М.В. До питання про організацію навчання дітей у малонаселених пунктах. Всеукраїнська науково-практична конференція з проблем роботи середніх загальноосвітніх навчально-виховних закладів нового типу: Тези доповідей та виступів. Випуск другий. К.: ІСДО, 1994. С.186-188.

6. Соловйов В.О. Деякі організаційно-педагогічні основи роботи навчально-виховних закладів нового типу на селі // Всеукраїнська науково-практична конференція з проблем роботи середніх загальноосвітніх навчально-виховних закладів нового типу: Тези доповідей та виступів. Випуск другий. К.: ІСДО, 1994. С.188-191. 


\section{References:}

1. Kontseptsiia rozvytku osvity Ukrainy na period 2015-2025 rokiv (proekt) (2014). [The concept of development of education in Ukraine for the period 2015-2025 (project)]. URL: http://old.mon.gov.ua/ua/pr-viddil/1312/1390288033/1414672797/[in Ukrainian].

2. Leontev A.N. (1983) Deiatelnost. Soznanie. Lichnost. [Activity. Consciousness. Personality]. Izbr. psikhol. proizvedeniia v 2-kh t. T.1.M.: Pedagogika, 291 s. [in Russian].

3. Dychkivska I.M. (2001) Osnovy pedahohichnoi innovatyky [Fundamentals of pedagogical innovation]: Navch.posibnyk. Rivne. 222 s. [in Ukrainian].

4. Voronina L.P., Kyzenko V.I. (1992) Fakultatyvni zaniattia yak zasib dyferentsiatsii navchannia $\mathrm{v}$ osnovnii shkoli. [Optional classes as a means of differentiation of education in primary school]. Pedahohika: Naukovo-metodychnyi zbirnyk. Vyp.31. K.: Osvita, 1992. S. 14-17. [in Ukrainian].

5. Paiul M.V. (1994) Do pytannia pro orhanizatsiiu navchannia ditei u malonaselenykh punktakh. [On the issue of organizing the education of children in sparsely populated areas]. Vseukrainska naukovo-praktychna konferentsiia $\mathrm{z}$ problem roboty serednikh zahalnoosvitnikh navchalno-vykhovnykh zakladiv novoho typu: Tezy dopovidei ta vystupiv. Vypusk druhyi. K.: ISDO, S.186-188. [in Ukrainian].

6. Soloviov V.O. (1994) Deiaki orhanizatsiino-pedahohichni osnovy roboty navchalnovykhovnykh zakladiv novoho typu na seli. [Some organizational and pedagogical bases of work of educational institutions of new type in the village] // Vseukrainska naukovo-praktychna konferentsiia $\mathrm{z}$ problem roboty serednikh zahalnoosvitnikh navchalno-vykhovnykh zakladiv novoho typu: Tezy dopovidei ta vystupiv. Vypusk druhyi. K.: ISDO. S.188-191. [in Ukrainian]. 